\title{
Pengaruh Pendekatan Spikk pada Pembelajaran Fisika Terhadap Prestasi Belajar Fisika
}

\author{
Fatimah \\ Pendidikan Fisika, STKIP Bima \\ Jl. Tendean Kel. Mande Kota Bima-NTB \\ Email : fathmariama@gmail.com
}

\begin{abstract}
ABSTRAK : Pembelajaran IPA khususnya fisika, memerlukan suatu cara pembelajaran siswa yang dapat mengatasi semua hambatan tersebut. Cara pembelajaran yang di maksud adalah cara pembelajaran siswa yang menekankan pada gagasan konsep fisika melalui cara berpikir kritis dan kreatif yang harus dilakukan oleh siswa, serta meningkatkan keberanian dan kemampuan siswa bertanya, menjawab, berdiskusi dan bereksperimen.

Tujuan penelitian ini adalah untuk mengetahui pengaruh pendekatan SPIKK pada pembelajaran fisika terhadap prestasi belajar fisika siswa kelas VII semester I di MTs NW Mataram Tahun Pelajaran 2012/2013. Jenis penelitian ini adalah penelitian eksperimen yaitu penelitian yang mencari hubungan sebab akibat antara dua faktor dengan maksud untuk melihat akibat suatu perlakuan. Berdasarkan hasil penelitian, diperoleh bawa, hasil pre test pada kelas eksperimen diperoleh nilai rata-rata sebesar 64,7, mengalami peningkatan pada post test yaitu dengan rata-rata 77,0. Sedangkan pada kelas kontrol, hasil pre test diperoleh nilai ratarata sebesar 62,5 dan pada post test yaitu dengan rata-rata 67,5. Berdasarkan hasil penelitian di atas, diketahui bahwa ada pengaruh secara signifikan yang dibuktikan dengan hasil uji-t tes dimana thitung $=3,0 \mathrm{I}>$ tabel $=\mathrm{I}, 99$ pada taraf kepercayaan $95 \%$, maka perlakuan yang diterapkan yakni ada pengaruh pendekatan SPIKK terhadap prestasi belajar fisika siswa kelas VII semester I di MTs NW Mataram Tahun Pelajaran 2012/2013.
\end{abstract}

Kata kunci : Pendekatan SPIKK dan Prestasi Belajar

\section{PENDAHULUAN}

Berbagai upaya dilakukan dalam meningkatkan mutu pendidikan salah satu adalah dengan cara menerapakan metode atau pendekatan pembelajaran yang baru. Metode atau pembelajaran tersebut perlu diuji cobakan penerapannya agar dapat digunakan oleh para guru dan dapat di sesuaikan dengan situasi dan kondisi di setiap sekolah.

Mata pelajaran fisika di SMP merupakan pengembangan dan pendalaman materi pelajaran IPA di sekolah dasar untuk mempelajari perilaku benda dan energi serta keterkaitan antara konsep dan penerapannya dalam kehidupan sehari-hari. Seperti yang diketahui pada saat sekarang ini pencapaian tujuan pengajaran IPA belum berhasil dengan baik disebabkan karena adanya berbagai hambatan, seperti pada MTs NW Mataram di kelas VIII semester ganjil, mata pelajaran IPA masih banyak ditemukan peserta didik yang kurang berminat, kurang antusias, dalam kegiatan belajar mengajar khususnya materi Fisika, tidak hanya itu, dapat ditemukan kendala dalam usaha untuk menciptakan kondisi interaktif dalam pembelajaran yaitu kurangnya sarana dan prasarana, sehingga nilai yang diperoleh pada mata pelajaran fisika masih tergolong rendah.

Oleh karena itu, pembelajaran IPA khususnya fisika, memerlukan suatu cara pembelajaran siswa yang dapat mengatasi semua hambatan tersebut. Cara pembelajaran yang di maksud adalah cara pembelajaran siswa yang menekankan pada gagasan konsep fisika melalui cara berpikir kritis dan kreatif yang harus dilakukan oleh siswa, serta meningkatkan keberanian dan kemampuan siswa bertanya, menjawab, berdiskusi dan bereksperimen. Cara membelajarkan siswa itu dengan sebutan pendekatan SPIKK (Siswa Berpikir Kritis dan Kreatif) yang di kembangkan oleh [I].

\section{METODE PENELITIAN}

Penelitian ini termasuk dalam penelitian percobaan (Experimental Researsh) yang merupakan jenis penelitian yang bertujuan melihat hubungan sebab akibat [2], Dengan cara memberikan perlakuan yaitu pendekatan SPIKK kepada suatu kelompok eksperimen.

Penelitian ini termasuk dalam penelitian eksperimen yang merupakan jenis penelitian yang bertujuan melihat hubungan sebab akibat, penelitian eksperimen ini menggunakan pretestpostest control group design [3] yang memiliki rancangan penelitian sebagai berikut:

Tabel 2. Rancangan penelitian

\begin{tabular}{cccc}
\hline Kelas & Pre-test & Perlakuan & Post-test \\
\hline Eksperimen & Ya & Ya & Ya \\
Kontrol & Ya & Tidak & Ya
\end{tabular}

Populasi dalam penelitian ini adalah seluruh siswa kelas VII MTs NW Mataram yang terdiri dari 2 kelas dengan sebaran sebagai berikut:

Tabel 3. Komposisi Anggota Populasi Penelitian

\begin{tabular}{cc}
\hline Kelas & Jumlah \\
\hline VIIA & 24 \\
VIIB & 24 \\
Jumlah & 48
\end{tabular}

Mengingat populasi dalam penelitian ini hanya terdiri dari dua kelompok yaitu dua kelas, yang berjumlah 48 siswa yang terbagi dalam dua kelas yaitu kelas VIIA sebanyak 24 siswa dan VIIB sebanyak 24 siswa. maka teknik pengambilan sampel dalam penelitian ini menggunakan teknik sampel jenuh yang merupakan jumlah sampel sama dengan jumlah populasi.

Instrumen penelitian yang digunakan dalam penelitian ini yaitu lembar Tes hasil belajar yang digunakan dalam penelitian ini tes pilihan ganda, yang terdiri dari 30 soal dan diberikan pada akhir pembelajaran. Teknik pengumpulan data menggunakan beberapa metode sebagai berikut: tes adalah serentetan pertanyaan atau latihan serta alat lain yang digunakan 
untuk mengukur keterampilan, pengetahuan inteligensi, kemampuan atau bakat yang dimiliki oleh individu atau kelompok [4]. Tes dilakukun untuk mengetahui sejauh mana penguasaan siswa terhadap konsep yang diberikan selama proses belajar mengajar menggunakan pendekatan SPIKK.

\section{a. Uji Coba Instrumen}

I. Uji validitas

Menghitung validitas item digunakan rumus korelasi point biserial ( $r p b i)$

$\mathrm{r}_{x y}=\frac{N \sum X Y-\left(\sum X Y\right)}{\sqrt{\left\{N \sum X^{2}-\left(\sum X\right)^{2}\right\}\left\{N \sum Y^{2}-\left(\sum Y\right)^{2}\right\}}}$

\section{Uji reliabilitas}

Mencari reliabilitas soal keseluruhan tes digunakan rumus $\mathrm{KR}-20$.

$$
r_{11}=\left(\frac{n}{n-1}\right)\left(\frac{S^{2}-\sum p q}{S^{2}}\right)
$$

3. Uji tingkat kesukaran butir soal

Untuk mencari tingkat indeks kesukaran (P) dengan rumus :

$$
P=\frac{B}{J S}
$$

4. Uji daya beda butir soal

Seluruh kelompok tes dibagi dua sama besar, 50\% kelompok atas dan 50\% kelompok bawah.

$$
\mathrm{D}=\frac{B_{A}}{J_{A}}-\frac{B_{B}}{J_{B}}
$$

b. Analisis Data

\section{Data Hasil Tes}

Data hasil tes belajar siswa diperoleh dari nilai hasil belajar siswa. Nilai hasil belajar siswa dihitung dugunakan rumus sebagai berikut:

$$
N=\frac{\text { Jumlah Skor Yang di Peroleh }}{\text { Jumlah Skor Maximal }} \times 100
$$

\section{Uji Homogenitas}

Sebelum dilakukan uji statistik dengan menggunakan rumus t-tes untuk membuktikan kebenaran hipotesis yang telah dibuat sebelumnya, maka perlu diuji varians kedua sampel homogen atau tidak. Pengujian homogenesis varians uji $F$ dengan rumus :

$$
F=\frac{\text { Varians Terbesar }}{\text { Varians Terkecil }}
$$

\section{Uji Hipotesis}

Uji statistik yang digunakan untuk menguji hipotesis yaitu uji t. Rumus yang digunakan untuk menguji hipotesis sampel yang homogen adalah rumus polled varians.

thitung $=$

$$
\frac{x_{a}-x_{b}}{\sqrt{\frac{\left(n_{1}-1\right) s_{1}^{2}+\left(n_{2}-1\right) s_{2}^{2}}{n_{1}+n_{2}-2}\left(\frac{1}{n_{1}}+\frac{1}{n_{2}}\right)}}
$$

Selanjutnya, nilai thitung dikonsultasikan dengan tabel pada taraf kepercayaan 95\%. Jika t-hitung $\geq \mathrm{t}$-tabel, maka terdapat perbedaan yang signifikan antara kelas dengan pemberian tugas terstruktur dan tanpa dengan pemberian tugas terstruktur. Sebaliknya jika t-hitung $<$ t-tabel, maka tidak terdapat perbedaan yang signifikan antara kelas eksperimen dan kontrol [6].

\section{HASIL DAN PEMBAHASAN}

I. Hasil Uji Validitas Instrumen

Hasil uji coba validitas instrumen dari 25 soal objektif terdapat 2I soal yang valid.

2. Data Hasil Penelitian

a. Data Hasil Belajar

Data hasil evaluasi belajar siswa dapat dilihat pada Tabel 4.I di bawah ini.

Tabel 4. Data Hasil Belajar Siswa

\begin{tabular}{lcccc}
\multirow{2}{*}{ Parameter } & \multicolumn{2}{c}{ Kelas Eksperimen } & \multicolumn{2}{c}{ Kelas Kontrol } \\
\cline { 2 - 5 } & Pre test & Post test & Pre test & Post test \\
\hline Jumlah Siswa & 24 & 24 & 24 & 24 \\
\hline Nilai Rata-rata & 64,7 & 77,0 & 62,5 & 67,5 \\
\hline Nilai Tertingi & 85,71 & 95,24 & 76,19 & 80,95 \\
\hline Nilai Terendah & 42,86 & 52,38 & 42,86 & 42,86
\end{tabular}

Hasil penelitian berupa nilai yang diperoleh dari hasil tes belajar yang diadakan setelah semua rangkaian kegiatan belajar mengajar pada kelas eksperimen dan kelas kontrol telah selesai dilaksanakan. Sebelum memulai pembelajaran dilakukan pre test pada kelas eksperimen dan kontrol. Hasil pre test pada kelas eksperimen diperoleh nilai ratarata sebesar 64,7, mengalami peningkatan pada post test yaitu dengan rata-rata 77,0. Sedangkan pada kelas kontrol, hasil pre test diperoleh nilai rata-rata sebesar 62,5 dan pada post test yaitu dengan rata-rata 67,5 .

\section{b. Hasil Uji t}

Data hasil belajar siswa dianalisis dengan uji t yaitu dengan membandingkan skor pada kelas eksperimen dan kelas kontrol. Berdasarkan uji $\mathrm{t}$ diperoleh thitung $=3,0 \mathrm{I}$. Hasil uji $\mathrm{t}$ diatas kemudian dikonsultasikan pada tabel. dengan taraf kepercayaan $95 \%$ dan $\mathrm{db}=78$ diperoleh tabel $=1,99$, karena thitung $\geq$ trabel. thitung $\geq$ tabel maka Hipotesis diterima, dengan demikian ada pengaruh pendekatan SPIKK terhadap prestasi belajar fisika siswa kelas VII semester I di MTs NW Mataram Tahun Pelajaran 2012/2013. Selengkapnya dapat dilihat pada table 4.2 di bawah ini

Tabel 5. Uji Hipotesis

\begin{tabular}{cccc}
\hline $\mathrm{N}$ & thitung & tabel & Keterangan \\
\hline 78 & 3,0I. & $\mathrm{I}, 99$ & Diterima \\
\hline
\end{tabular}

Berdasarkan data hasil belajar siswa, diperoleh bahwa nilai rata-rata kelas eksperimen lebih tinggi daripada kelas kontrol. Perbedaan ini signifikan yang dibuktikan dengan hasil uji t-tes dimana $t_{\text {hitung }}=3,0$ I lebih besar daripada $t_{\text {tabel }}=1,99$. Hasil ini menunjukkan bahwa ada pengaruh pendekatan SPIKK terhadap prestasi belajar fisika siswa kelas VII semester I di MTs NW Mataram Tahun Pelajaran 2012/2013 dibandingkan dengan metode konvensional, walaupun demikian terdapat siswa yang memperoleh nilai yang sangat rendah pada kelas eksperimen yakni 52,38. Kondisi ini menunjukkan bahwa masih ada siswa yang kemampuannya kurang. Guru yang memiliki kemampuan kurang hendaknya dapat lebih memberikan bimbingan secara individual kepada siswa sehingga pembelajaran dengan menggunakan model pembelajaran 
kontekstual dengan strategi bertanya dapat lebih mengefektifkan siswa dalam belajarnya.

Hal tersebut di atas diperlukan karena keterbukaan siswa untuk mengungkapkan petanyaaan atau kesulitan dalam memahami materi pelajaran adalah salah satu dari beberapa faktor yang mempengaruhi prestasi belajarnya, sehingga hasil belajar fisika kelas VII semester I di MTs NW Mataram dapat ditingkatkan.

\section{KESIMPULAN}

Berdasarkan hasil penelitian dan hasil analisis data yang dilakukan, dapat disimpulkan bahwa ada pengaruh pendekatan SPIKK terhadap prestasi belajar fisika siswa kelas VII di MTs NW Mataram Tahun Pelajaran 2012/2013, dimana thitung $3,0 \mathrm{I}>\mathrm{t}_{\text {tabel }}=\mathrm{I}, 99$. Hasil uji t di atas dengan taraf kepercayaan $95 \%$ dan $\mathrm{db}=48$

\section{DAFTAR PUSTAKA}

[I] Darliana, Drs. 2008. Pendekatan SPIKK Bandung: Departemen Pendidikan Dan Kebudayaan.

[2] Sudjana, Nana. 200I. Statistik Pendidikan. Bandung: Tarsito.

[3] Arikunto. 20I0. Dasar-Dasar Evaluai Pendidikan. Jakarta: Bumi aksara.

[4] Arikunto. 2006. Dasar-Dasar Evaluai Pendidikan. Jakarta: Bumi aksara.

[5] Arikunto. 2008. Dasar-Dasar Evaluai Pendidikan. Jakarta: Bumi aksara.

[6] Sugiyono, dkk.(2010) Petunjuk Guru Fisika SLTP. Bandung: Transito. 